\title{
On several new or poorly-known Oriental Paradoxosomatidae (Diplopoda: Polydesmida), XII
}

\section{О несколыких новых или плохоизученных ориенталыных Paradoxosomatidae (Diplopoda: Polydesmida), XII}

\author{
S.I. Golovatch \\ С.И. Головач
}

Institute for Problems of Ecology and Evolution, Russian Academy of Sciences, Leninsky prospekt 33, Moscow 119071 Russia. E-mail: sgolovatch@yandex.ru

Институт проблем экологии и эволюции РАН, Ленинский проспект, 33, Москва 119071 Россия.

KEY WORDS: Diplopoda, Polydesmida, Paradoxosomatidae, Sulciferini, taxonomy, new genus, new species, Sichuan, China.

КЛЮЧЕВЫЕ СЛОВА: Diplopoda, Polydesmida, Paradoxosomatidae, Sulciferini, таксономия, новый род, новые виды, Сычуань, Китай.

ABSTRACT. This contribution is devoted to descriptions of three new species from Sichuan, China: Hedinomorpha reducta sp.n. (with a review and a new diagnosis of the genus, and a key to all of its four constituent species), Inversispina erectispina sp.n. and Belousoviella kabaki sp.n. A key is given to all five genera of Asian Paradoxosomatidae that share elongate, slender gonopod femorites, coupled with long, more or less strongly coiled, uni- or biramous solenophores that sheath similarly long and flagelliform solenomeres, with formal allocations or transfers of these genera into the tribe Sulciferini, Paradoxosomatinae: Kaschmiriosoma Schubart, 1935, Gonobelus Attems, 1936, Wulingina Zhang, in Zhang, Wang \& Zhang, 1997, Inversispina Zhang, in Zhang, Wang \& Zhang, 1997, and Belousoviella gen.n.

РЕЗЮМЕ. Данное сообщение посвящено описаниям трех новых видов из Сычуани (Китай): Hedinomorpha reducta sp.n. (с обзором и новым диагнозом рода, а также ключом для всех четырех входящих в него видов), Inversispina erectispina sp.n. и Belousoviella kabaki sp.n. Представлен ключ для определения всех пяти родов азиатских Paradoxosomatidae, у которых наблюдаются удлиненные и стройные фемориты гоноподов в сочетании с длинными, более или менее сильно закрученными, одноили двуветвистыми соленофорами, которые облегают сходной длины жгутиковидные соленомеры, с формальным отнесением или перемещением этих родов в состав трибы Sulciferini, Paradoxosomatinae: Kaschmiriosoma Schubart, 1935, Gonobelus Attems, 1936, Wulingina Zhang, in Zhang, Wang \& Zhang, 1997, Inversispina Zhang, in Zhang, Wang \& Zhang, 1997, и Belousoviella gen.n.

\section{Introduction}

This paper is devoted to descriptions of three further paradoxosomatid species from Sichuan Province, southern China. The material has largely been deposited in the Zoological Museum, Moscow State University, Russia (ZMUM), with a few paratypes shared with the collections of the Zoological Institute, Russian Academy of Sciences, St. Petersburg (ZIN), the Natural History Museum of Denmark, Copenhagen (ZMUC), and the Muséum national d'Histoire naturelle, Paris (MNHN), as indicated below.

\section{Taxonomic part}

Oxidus gracilis (C.L. Koch, 1847)

MATERIAL. 4 of (ZMUM), China, Hebei Prov., NW of Beijing, Damaqun Shan, $40.50472^{\circ} \mathrm{N}, 115.81347^{\circ} \mathrm{E}, 11-$ 12.VIII.2010, leg. Y. Marusik. $10^{7}$ (ZMUM), Sichuan Prov., E of Mianning, ca $1840 \mathrm{~m}$ a.s.1., $28^{\circ} 32^{\prime} 54^{\prime \prime} \mathrm{N}, 102^{\circ} 12^{\prime} 11^{\prime \prime} \mathrm{E}, 04$. VII.2011, leg. I. Belousov \& I. Kabak.

REMARKS. This nearly ubiquitous species of East Asian origin has long been known from several places in China, including Sichuan Province [Geoffroy \& Golovatch, 2004].

\section{Hedinomorpha reducta sp.n. \\ Figs 1-12.}

HOLOTYPE $0^{7}$ (ZMUM), China, Sichuan Prov., SW of Mianning, right tributary of Yalongjiang River Canyon, ca $9 \mathrm{~km}$ SW of Mofanggou, $28^{\circ} 14^{\prime} 08^{\prime \prime} \mathrm{N}, 101^{\circ} 44^{\prime} 29^{\prime \prime} \mathrm{E}$, ca $2900 \mathrm{~m}$ a.s.l., dark humid subtropical broadleaved forest, litter and rotten wood, 12.VII.2011, leg. I. Belousov \& I. Kabak.

PARATYPE: 1 ( (ZMUM), same locality, together with holotype. 

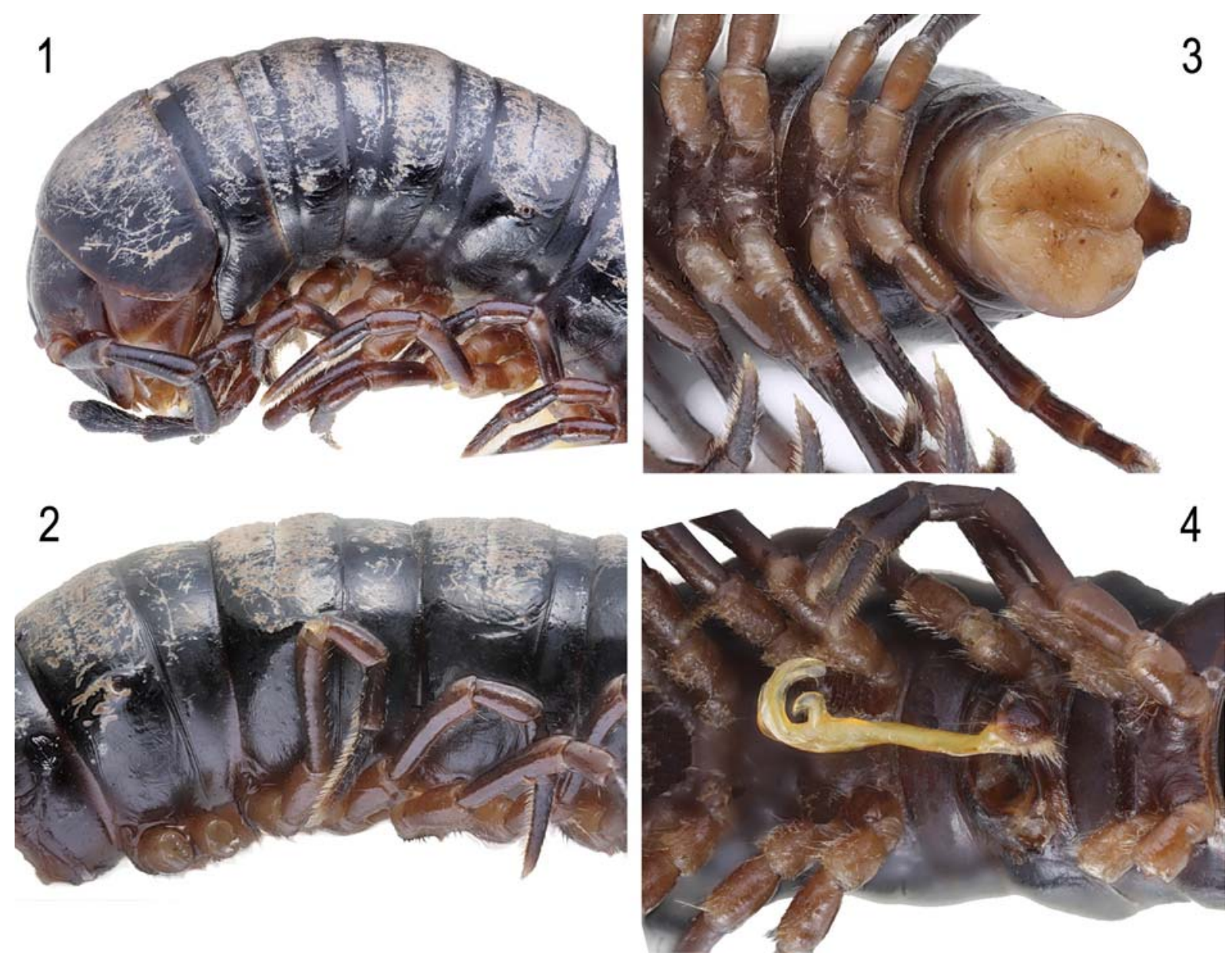

Figs 1-4. Hedinomorpha reducta sp.n., $0^{\top}$ holotype: 1 - anterior part of body, lateral view; 2 - body segments 9-11, lateral view; 3 - posterior part of body, ventral view; 4 - body segments 6 and 7, ventral view. Photos taken by K. Makarov, not to scale.

Рис. 1-4. Hedinomorpha reducta sp.n., голотип О: 1 - передняя часть тела, вид сбоку; 2 - туловищные сегменты 9-11, вид сбоку; 3 - задняя часть тела, вид снизу; 4 - туловищные сегменты 6 и 7, вид снизу. Фото сделаны К. Макаровым, без масштаба.

NAME. To emphasize the particularly strongly reduced paraterga.

DIAGNOSIS. Differs from all congeners in the particularly strongly reduced paraterga, the absence of a mesal groove/hollow on a particularly slender gonopod femorite, and the relatively simple, subacuminate solenophore.

DESCRIPTION. Length ca 35 (holotype) or 38 $\mathrm{mm}$ (paratype), width of midbody pro- and metazona 3.0 and 3.5 (holotype) or 3.7 and $3.9 \mathrm{~mm}$ (paratype), respectively. General coloration in alcohol rather uniformly blackish brown; head (except for vertigial region), venter and basal podomeres (coxa, prefemur, sometimes also femur and postfemur) a little lighter, brown to dark brown. Gonopod coxite and prefemoral part dark brown, acropodite yellow (Fig. 4).

In width, head $=$ collum $=$ segments $5-15>2=3=$ 4 ; starting from segment 16 , body gradually tapering towards telson. Clypeolabral region rather densely setose, vertigial region bare (Fig. 1). Antennae slender and relatively short, reaching behind segment $3\left(\sigma^{7}\right)$ or

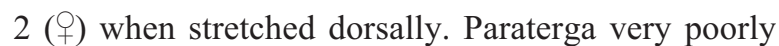
developed to wanting (Figs 1, 2 \& 5), set low, mostly lying at about 1/3-1/2 midbody height; paraterga 2 most prominent, lying particularly low, as a distinct, large, roundly subtriangular lobe produced anteriad (Figs 1 \& 5); following paraterga either as low, small, lateral bulges a little better developed and delimited dorsally by a sulcus on poriferous segments (especially so in $\sigma^{\prime}$ compared to + ) or usually as vague sulci/lines on poreless segments (up to virtually missing there in +) (Figs 1, 2 \& 5). Ozopores lateral, mostly lying at about $1 / 2-1 / 3$ metatergal length in front of caudal margin (Figs 1, 2 \& 5), only in segments 17-19 shifted increasingly close to the margin. Body surface mostly smooth and shining, metaterga and sides often very faintly rugulose, a little better so laterally in segments 2-5 (Figs $1 \& 5$ ), also microgranulate in pleurosternal region of segments $2-4$. Axial line on metaterga largely missing, at most very vague. Transverse metatergal sulcus evident in segments 5-17, never reaching bases of paraterga. Tergal setae wanting, pattern untraceable. 


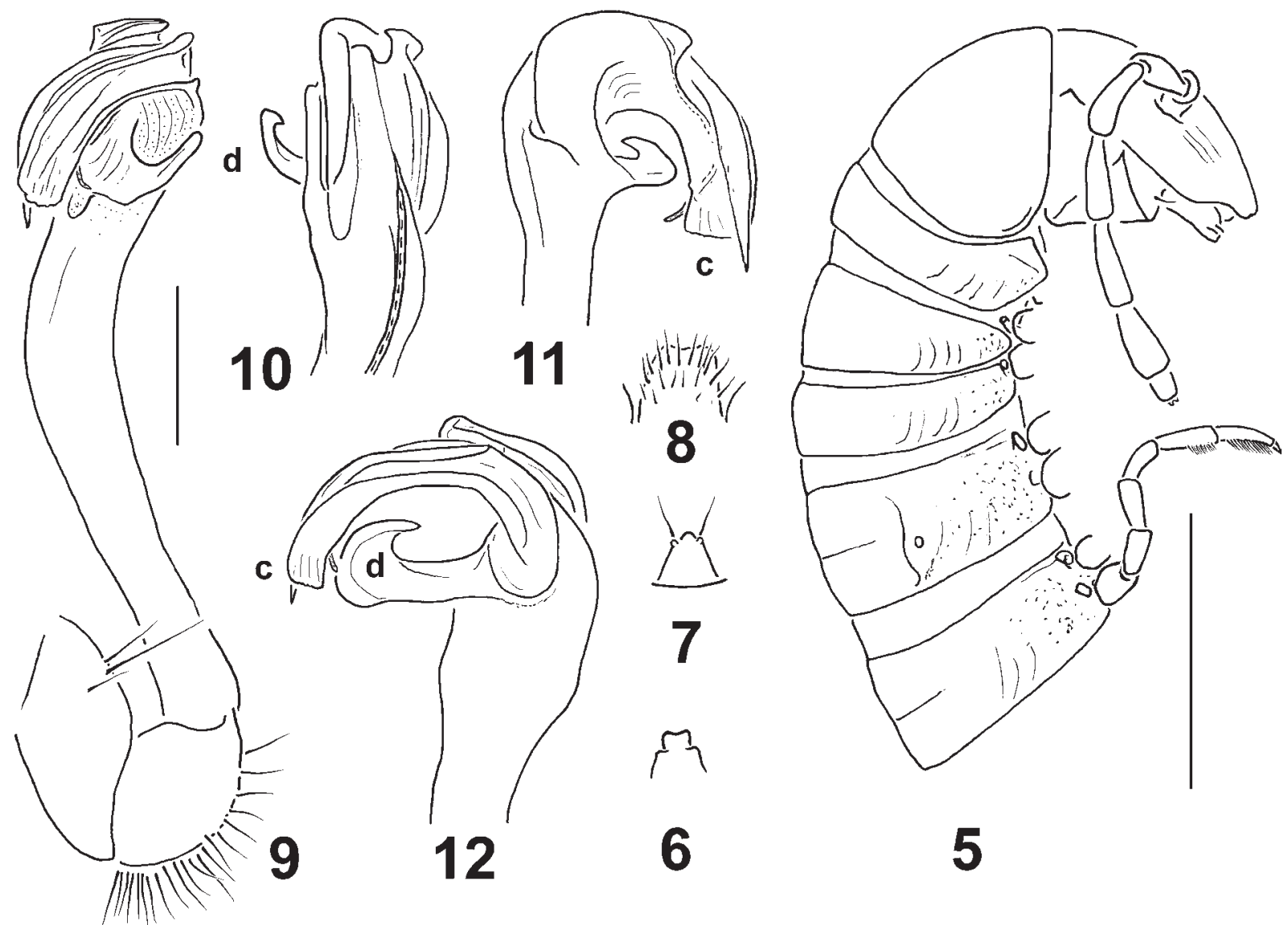

Figs 5-12. Hedinomorpha reducta sp.n., o holotype: 5 - anterior part of body, lateral view; 6 - epiproct, dorsal view; 7 hypoproct, ventral view; 8 - sternal lamina between coxae 4, caudal view; 9-12 - right gonopod, lateral, mesal, dorsal and ventral views, respectively. Scale bars: $2.0(5-8)$ and $0.5 \mathrm{~mm}(9-12)$.

Рис. 5-12. Hedinomorpha reducta sp.n., голотип О7: 5 - передняя часть тела, вид сбоку; 6 - эпипрокт, вид сверху; 7 гипопрокт, вид снизу; 8 - стернальная пластина между тазиками 4, вид сзади; 9-12 - правый гонопод, соответственно сбоку, изнутри, сверху и снизу. Масштаб: 2,0 (5-8) и 0,5 мм (9-12).

Stricture dividing pro- and metazona narrow, finely striolate down to about $1 / 2$ body height (Figs $1 \& 2$ ). Pleurosternal carinae present as small bulges only on segments 2 and 3. Epiproct (Figs 3 \& 6) rather short, normal, flattened dorsoventrally, tip narrowly concave, subapical papillae evident. Hypoproct (Fig. 7) high, linguiform, caudal $1+1$ setae borne on minute knobs and rather evidently separated.

Sternites without modifications, sparsely setose, cross-impressions very modest (Figs 3 \& 4); a roundly subtrapeziform, setose lamina only between $\sigma^{7}$ coxae 4 (Fig. 8). Legs slender, long (Figs 1-5), ca 1.4-1.5 ( $\left.\mathrm{O}^{7}\right)$ or 1.0-1.1 times ( + ) as long as midbody height; $\sigma^{7}$ prefemora without evident lateral bulges; ventral brushes present in $\sigma^{7}$ tibiae until legs of segment 16, on $\sigma^{7}$ tarsi absent only from last two legs; adenostyles absent.

Gonopods (Figs 4 \& 9-12) relatively simple; coxite short, subcylindrical, setose distodorsally; femorite very slender, strongly elongate, simple, with neither evidence of torsion nor a mesal groove/hollow; solenophore composed of a somewhat hypertrophied, apically acuminate lamina lateralis (c) and a smaller lamina medialis, both laminae being directed laterad, sheathing most of a flagelliform solenomere and showing an evident, unciform, lateral process (d) at base.

REMARKS. The genus Hedinomorpha Verhoeff, 1933, has hitherto been known to encompass only three valid species: $H$. hummelii Verhoeff, 1933 (the type species, with two varieties), from the southern part of Gansu Province, central China; H. bucharensis (Lohmander, 1933), from Tajikistan, Central Asia, and $H$. biramipedicula Zhang \& Tang, 1985, from Qinling Mountains, lying across the southern part of Shanxi Province, northern China [Verhoeff, 1933; Zhang \& Tang, 1985; Jeekel, 1988]. H. reducta sp.n. is yet the southernmost congener, probably confined to Sichuan Province, southern China.

Hedinomorpha seems to be one of the northernmost native genera of Paradoxosomatidae to inhabit Asia [Jeekel, 1988]. Only a few Asian genera, Haplogonosoma Brölemann, 1916, Sichotanus Attems, 1914, Cawjeekelia Golovatch, 1980, occur even more northerly in also populating the Russian Far East [Mikhaljova, 2004], while several Kaschmiriosoma species have 
been encountered in northern Pakistan [Jeekel, 2003].

As regards Kaschmiriosoma, Sichotanus, Cawjeekelia and Hedinomorpha, they all belong to the same, largely Central to East and Southeast Asian tribe Sulciferini. Based on gonopod traits alone, Hedinomorpha seems to be especially similar to Cawjeekelia. Indeed, these two genera have heretofore been considered as the only sulciferines, in which the distal parts of the gonopods (solenophore and solenomere) are directed laterad, not mesad [Jeekel, 1988]. Cawjeekelia has recently been reviewed, rediagnosed and shown to comprise ten species, all keyed [Golovatch, 2011]. The main differences between Hedinomorpha and Cawjeekelia lie only in gonopod conformation, whereas peripheral characters overlap too broadly to be of any use. Thus, the paraterga, claimed as being rather distinct and keel-shaped in Hedinomorpha versus poorly developed and ridge-like in Cawjeekelia [Jeekel, 1988], no longer hold, because these in $H$. reducta sp.n. are particularly strongly reduced, mostly missing to retained only as vague sulci or lines in poreless segments.

A new diagnosis of Hedinomorpha would read as follows.

\section{Hedinomorpha Verhoeff, 1933}

DESCRIPTION. Medium- to rather large-sized (ca $1.8-4.0 \mathrm{~cm}$ long) Sulciferini with paraterga from evident (usually) to nearly missing (more rarely), set mostly at $1 / 4$ to $1 / 3$ metasomital height. Adenostyles on $\sigma^{7}$ legs missing. A transverse setose lobe between $\sigma^{7}$ coxae 4 present.

Gonopod coxite elongate, usually evidently shorter than telopodite, subcylindrical, setose distoventrally. Prefemoral region as usual, densely setose, from nearly as long as to $>3$ times shorter than femorite. The latter from about as long as (usually) to much longer than solenophore, elongate, rather (usually) to very slender (more rarely), at most only slightly enlarged distally, devoid of any processes, with (usually) or without (more rarely) a faint mesal groove, set off from solenophore by a distinct cingulum lying at base of a long, flagelliform solenomere. Seminal groove on femorite entirely mesal; solenomere at base also entirely mesal, sheathed by a long, slender and rather simple solenophore supporting only a single lateral process (d) at base; both solenomere and solenophore directed laterad, only slightly coiled; lamina lateralis of solenophore from about as well as (usually) to only somewhat better developed (more rarely) than lamina medialis.

Type species: Hedinomorpha hummelii Verhoeff, 1933, by monotypy.

DIAGNOSIS. Gonopod coxite much shorter than telopodite. Femorite elongate, slender, from a little to much longer than either prefemoral portion or solenophore, without evidence of torsion, usually with a rather vague mesal groove. Solenophore either represented by subequally well developed laminae or lamina lateralis somewhat hypertrophied, both laminae being rather simple, concealing much or most of a long, flagelliform solenomere, with a considerable lateral process (d) near base; both solenophore and solenomere directed laterad and only slightly coiled.

The following key can be proposed for separating the Hedinomorpha species. It mainly holds for $\sigma^{7} \sigma^{7}$.

1(2) Adults larger: body width $\geq 3.5 \mathrm{~mm}$. Paraterga very poorly developed, low bulges to nearly missing (Figs 1, $2 \& 5$ ). Lobe between $\sigma^{7}$ coxae 4 linguiform, higher than broad (Fig. 8). Gonopod femorite particularly slender, devoid of a mesal groove (Fig. 9), lateral process $\mathbf{d}$ at base of an acuminate solenophore unciform (Figs 9-12). Sichuan, China. ............................... H. reducta sp.n.

2(1) Adults smaller: body width $\leq 3.0 \mathrm{~mm}$. Paraterga keelshaped, at least those in caudal body third extending behind rear tergal margin. Lobe between $\sigma^{7}$ coxae 4 much more stout, about twice broader than high. Gonopod femorite far less slender, supplied with a vague mesal groove, lateral process $\mathbf{d}$ at base of a non-acuminate solenophore shorter or much longer, not unciform. .... 3

3(4) Epiproct normal. Lateral process d at base of solenophore a short, slender, subtruncate lobe. Tajikistan. H. bucharensis

4(3) Epiproct club-shaped. Lateral process $\mathbf{d}$ at base of solenophore a long ribbon. ........................................... 5

5(6) Adults larger: length $26 \mathrm{~mm}$. Lateral process $\mathbf{d}$ at base of solenophore bifid. Shanxi, China.

H. biramipedicula

6(5) Adults smaller: length $22-23 \mathrm{~mm}$. Lateral process $\mathbf{d}$ at base of solenophore subtruncate. Gansu, China.

H. hummelii

\section{Inversispina erectispina $\mathbf{s p . n .}$}

Figs 13-21.

HOLOTYPE $0^{7}$ (ZMUM), China, Sichuan Prov., SW of Mianning, right tributary of Yalongiiang River Canyon, $28^{\circ} 13^{\prime} 45^{\prime \prime}$ $\mathrm{N}, 101^{\circ} 43^{\prime} 07^{\prime \prime} \mathrm{E}$, ca $3760 \mathrm{~m}$ a.s.l., near upper timber-line, humid alpine meadows with remains of logged wood on karst outcrops, 07.VII.2011, leg. I. Belousov \& I. Kabak.

PARATYPES: $2 \sigma^{7} \sigma^{7}, 1$ ( 1 (ZMUM), same locality, together with holotype; $20^{7} 0^{7}$ (ZIN), same locality, $28^{\circ} 14^{\prime} 19^{\prime \prime} \mathrm{N}, 101^{\circ} 42^{\prime} 48^{\prime \prime}$

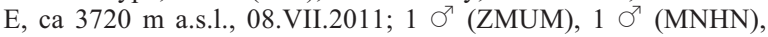
same locality, $28^{\circ} 15^{\prime} 19^{\prime \prime} \mathrm{N}, 101^{\circ} 43^{\prime} 26^{\prime \prime} \mathrm{E}, 4150 \mathrm{~m}$ a.s.1., 09.VII.2011; $2 \mathrm{O}^{\top} \mathrm{O}^{7}$ (ZMUC), Sichuan Prov., NW of Pingchuan, 27 $41^{\prime} 20^{\prime \prime} \mathrm{N}$, $101^{\circ} 47^{\prime 2} 22^{\prime \prime}$ E, $2315 \mathrm{~m}$ a.s.1., humid broadleaved forest, 15.VII.2011; 2 우 (ZMUM), same locality, $27^{\circ} 39^{\prime} 55^{\prime \prime} \mathrm{N}, 101^{\circ} 44^{\prime} 28^{\prime \prime} \mathrm{E}$, ca 3450 m a.s.1., 16.VII.2011; $20^{7} 0^{7}$ (ZMUM), same locality, 270 40'04" N, $101^{\circ} 44^{\prime} 08^{\prime \prime}$ E, ca $3790 \mathrm{~m}$ a.s.1., 17.VII.2011; 1 क (ZMUM), same locality, $27^{\circ} 40^{\prime} 04^{\prime \prime} \mathrm{N}, 101^{\circ} 44^{\prime} 04^{\prime \prime} \mathrm{E}, 3380-3665 \mathrm{~m}$ a.s.1.,

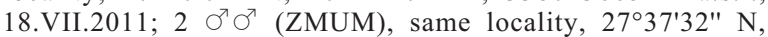
$101^{\circ} 466^{\prime} 31^{\prime \prime}$ E, ca $2400 \mathrm{~m}$ a.s.l., humid broadleaved forest, 19.VII.2011; 1 (ZIN), Sichuan Prov., Pass Pingchuan-Yanyuan, $27^{\circ} 31^{\prime} 51^{\prime \prime} \mathrm{N}, 101^{\circ} 42^{\prime} 43^{\prime \prime}$ E, ca $3210 \mathrm{~m}$ a.s.l., Pinus plantation, 20.VII.2011, all leg. I. Belousov \& I. Kabak.

NAME. To emphasize that both subequal spines located at the base of the solenophore are suberect.

DIAGNOSIS. Differs from both known congeners in being much larger (width 2.6-4.0 versus 1.4-1.5 $\mathrm{mm}$ in I. taiwanensis Chen, Golovatch \& Chang, 2011, or $2.0 \mathrm{~mm}$ in I. tortiapicalis Zhang, in Zhang, Wang \& Zhang, 1997) and, above all, by showing both spines located at the base of the solenophore subequal, suberect and directed distad. 

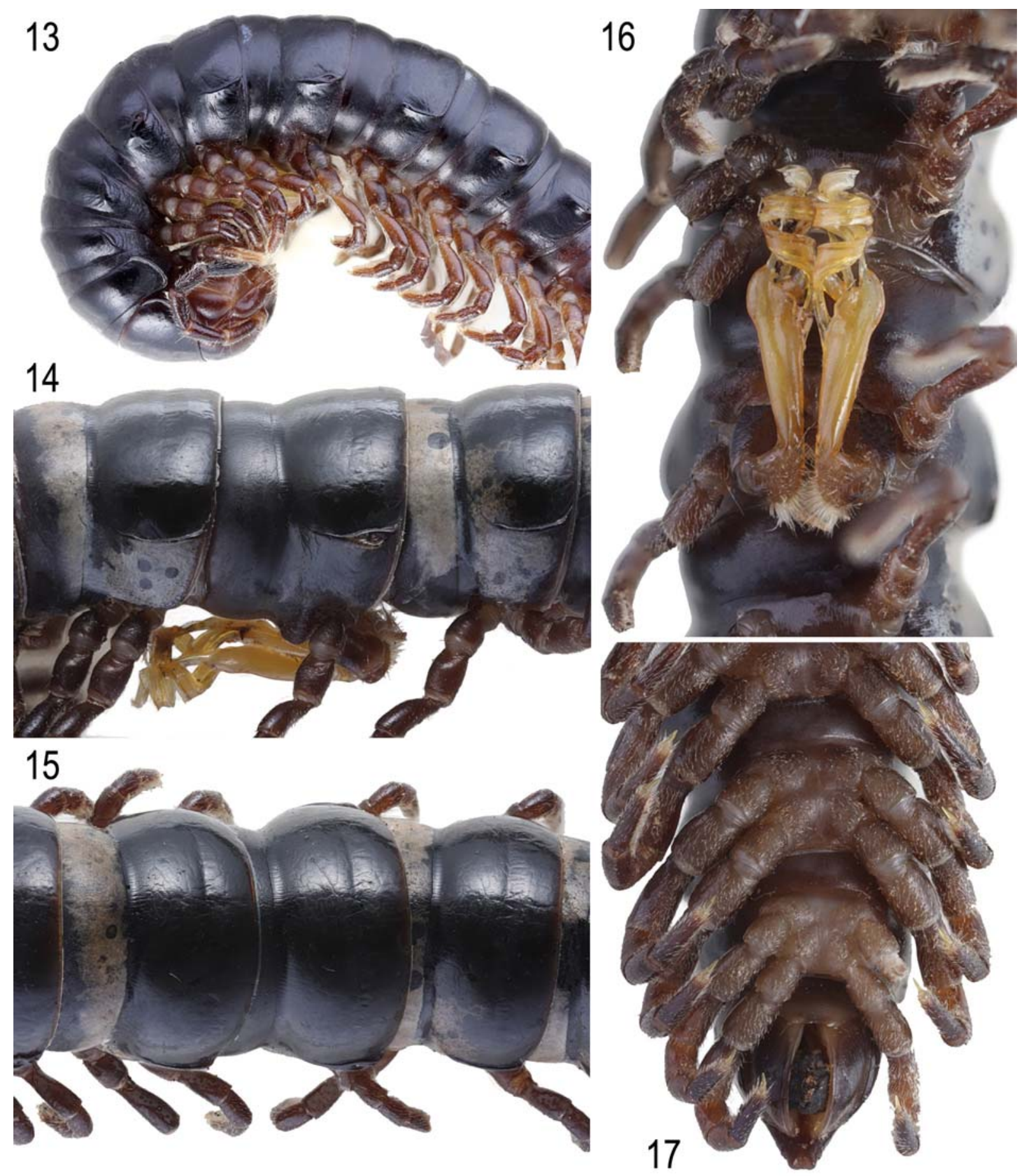

Figs 13-17. Inversispina erectispina sp.n., $0^{7}$ paratype from SW of Mianning: 13 - anterior part of body, lateral view; $14 \& 15-$ body segments 6-8, lateral and dorsal views, respectively; 16 - body segments 6 and 7, ventral view; 17 - posterior part of body, ventral view. Photos taken by K. Makarov, not to scale.

Рис. 13-17. Inversispina erectispina sp.n., паратип O’, на юго-восток от Мьаннина: 13 - передняя часть тела, вид сбоку; 14 и 15 - туловищные сегменты 6-8, соответственно сбоку и сверху; 16 - туловищные сегменты 6 и 7, вид снизу; 17 - задняя часть тела, вид снизу. Фото сделаны К. Макаровым, без масштаба. 


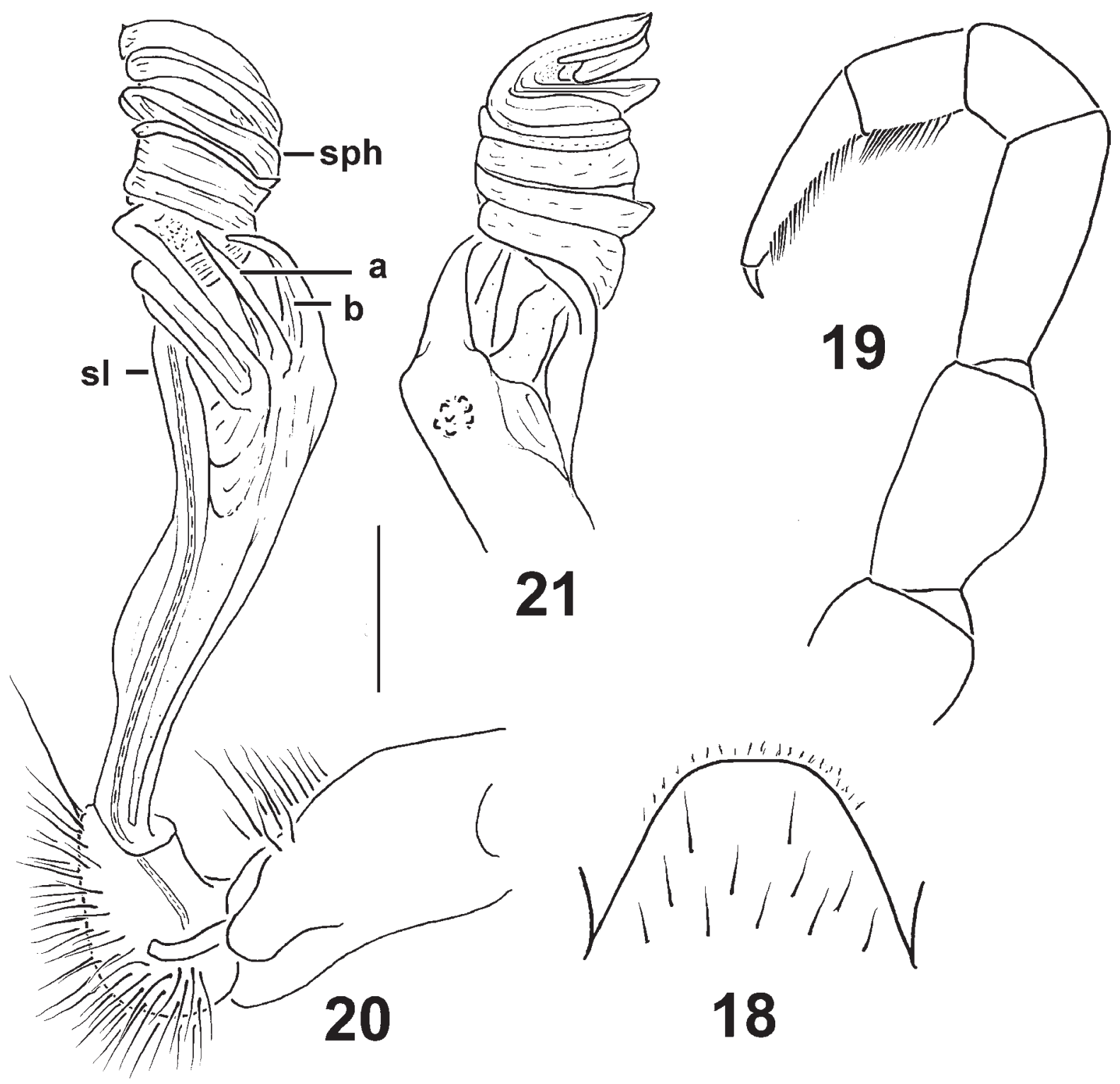

Figs 18-21. Inversispina erectispina sp.n., ơ paratype from Mianning: 18 - sternal lamina between coxae 4, caudal view; 19 - leg 9, front view; $20 \& 21$ - right gonopod, mesal and lateral views, respectively. Scale bar: $0.5 \mathrm{~mm}$.

Рис. 18-21. Inversispina erectispina sp.n., паратип $\sigma^{7}$, на юго-восток от Мьаннина: 18 - стернальная пластина между тазиками 4, вид сзади; 19 - нога 9, вид спереди; 20 и 21 - правый гонопод, соответственно изнутри и сбоку. Масштаб: 0,5 мм.

DESCRIPTION. Length ca $25-30 \mathrm{~mm}$ in both sexes, width of midbody pro- and metazona $2.4-2.7$ and $2.6-3.1\left(\sigma^{7}\right)$ or $3.0-3.5$ and $3.5-4.0 \mathrm{~mm}(+)$, respectively. Holotype ca $30 \mathrm{~mm}$ long, 2.7 and $3.0 \mathrm{~mm}$ wide on midbody pro- and metazona, respectively. General coloration in alcohol rather uniformly blackish brown to dark brown or brown, $\sigma^{7}$ usually more infuscate than +; vertigial region marbled red-brown; genae and venter light brown to yellowish; legs usually brown, infuscate, dark brown distally; gonopod coxite and prefemoral part brown, acropodite yellow (Figs $14 \& 16$ ).

In width, head $<$ segments 3 and $4<$ collum $<$ segment $2 \leq 5-16$; thereafter body gradually tapering towards telson. Clypeolabral region densely setose, ver- tigial region with a few setae only. Antennae slender and relatively short, extending slightly behind metatergum $2\left(\sigma^{7}\right)$ or collum $(+)$ when stretched dorsally. Paraterga poorly developed (Figs 13-15), set low, mostly lying at about $1 / 3-1 / 2$ midbody height; paraterga 2 most prominent, lying particularly low, as a distinct, large, rounded lobe (Fig. 13); following paraterga as low, thin, arcuate ridges a little better developed in $\sigma^{7}$ compared to $q$, delimited by a sulcus dorsally and, in caudal $1 / 2-1 / 3$, ventrally, especially small in segment 19 , a little broadened due to ozopores in pore-bearing segments, broadly rounded anteriorly, more narrowly rounded and never extending behind rear tergal margin caudally. Ozopores lateral, placed inside an ovoid 
groove, mostly lying at about $1 / 4$ metatergal length in front of caudal margin, only in segments 17-19 shifted increasingly close to the margin. Body surface mostly smooth and shining, metaterga and sides often faintly rugulose, sides striolate and microgranulate until about midbody segments, a little better so in segments 2-4. Axial line on metaterga missing. Transverse metatergal sulcus evident in segments 5-17(18), rather shallow and smooth, far from reaching bases of paraterga. Tergal setae mostly abraded, about 1/3-1/4 the length of metaterga, pattern mostly traceable as poorly discernible insertion points arranged in three transverse rows on collum, as one front row of $2+2$ setae until segment 19 , as two transverse rows of $2+2$ and $2+2$ setae on segment $19 ; 1-2$ insertion points also visible at lateral margin of paraterga. Stricture dividing pro- and metazona finely striolate down to about $1 / 2$ body height. Pleurosternal carinae complete in segments $2-6$, retained in segment 7 as a caudal bulge, thereafter missing $\left(\mathrm{O}^{7}\right)$, or as small ridges in segments 2-4 (†). Epiproct (Fig. 17) rather short, flattened dorsoventrally, tip narrowly concave, subapical papillae evident. Hypoproct (Fig. 17) rather high, subtrapeziform, caudal $1+1$ setae borne on evident knobs and clearly separated.

Sternites without modifications, sparsely setose, cross-impressions very modest (Figs $16 \& 17$ ); a rounded, setose, rather low lamina only between $\sigma^{7}$ coxae 4 (Fig. 18). Legs (Figs 13, 17 \& 19) evidently incrassate and longer in $\sigma^{7}$ as compared to + , rather short, ca 1.2$1.3\left(\bigcirc^{7}\right)$ or $0.9-1.0$ times $(+)$ as long as midbody height; $\sigma^{7}$ prefemora without evident lateral bulges; $\sigma^{7}$ legs very densely setose ventrally, ventral brushes present in $\sigma^{7}$ tibiae and tarsi until two last leg-pairs; adenostyles absent.

Gonopods (Figs 16, 20 \& 21) rather complex; coxite rather short, evidently shorter than femorite, subcylindrical, setose distodorsally; femorite slender, clearly enlarged distally, with neither evidence of torsion nor a mesal groove/hollow; solenophore strongly coiled, subacuminate apically, both a lamina lateralis and a lamina medialis subequally well developed, sheathing most of a flagelliform solenomere and showing two evident, spiniform, lateral, subequal and suberect processes (a and b) at base. Solenomere (sl) starting evidently basal to solenophore (sph).

REMARKS. The genus Inversispina Zhang, in Zhang, Wang et Zhang, 1997, has hitherto been known to comprise only two species: I. tortiapicalis Zhang, in Zhang, Wang \& Zhang, 1997 (the type species), from a south-temperate woodland at $1100 \mathrm{~m}$ elevation in the Wuling Mountains, southern Hubei Province, central China $\left(29.8^{\circ} \mathrm{N}, 110.0^{\circ} \mathrm{E}\right)$, and I. taiwanensis Chen, Golovatch \& Chang, 2011, from low- to midmontane woodlands in the northern and northeastern parts of Taiwan [Zhang et al., 1997; Chen et al., 2011]. The new species differs primarily in both processes located at the base of the solenophore being subequal and suberect, as opposed to process a being retrorse (= directed basally) in both other species known.

Chen et al. [2011], when rediagnosing the genus, pointed out the absence of adenostyles on $\sigma^{7}$ femora in I. taiwanensis, as opposed to their presence on $\sigma^{7}$ femora 1-9 in I. tortiapicalis. In general, because adenostyles on $\sigma^{7}$ femora 1 are highly characteristic of the subfamily Alogolykinae, this genus, following Zhang et al. [1997] who compared it only to Yuennanina Attems, 1936, remained formally allocated within that subfamily. However, in the light of the discovery of the above third congener, as well as of the new genus and species described below that appears to be quite similar to Inversispina, the former allocation requires revision.

There are only very few paradoxosomatid genera in Asia, in which at least some of the constituent species show elongate, slender gonopod femorites, coupled with long, more or less strongly coiled, uni- or biramous solenophores that sheath/support similarly long and flagelliform solenomeres. These genera are Kaschmiriosoma Schubart, 1935 (several species ranging from the Himalaya of India to northern Pakistan, see review by Jeekel [2003], ultimately placed in Sulciferini, Paradoxosomatinae), Gonobelus Attems, 1936 (monotypic, from Yunnan Province, China, see Attems [1936, 1937], still remaining ungrouped [Jeekel, 1968]), Wulingina Zhang, in Zhang, Wang \& Zhang, 1997 (two species from Hubei Province, China, see Zhang et al. [1997], also remaining ungrouped, except for it having originally been compared to Yuennanina alone, but without mentioning any adenostyles), as well as Inversispina. Jeekel [1968] has long noted particularly strong similarities in gonopod conformation in both Gonobelus and Kaschmiriosoma, whereas Zhang et al. [1997] considered both Wulingina and Inversispina as being especially similar to Yuennanina, an alogolykine genus. To my mind, however, these four genera seem to be especially close to one another and, on account of showing 1-2 evident outgrowths, usually spines or lobes, at the base of a twisted solenophore, they actually belong in the tribe Sulciferini. Belousoviella gen.n. definitely joins this group of genera as well (see below).

The following key can be proposed for separating the above five genera.

1(2) Gonopod femorite with a distinct, evidently sinuate, mesal groove. Solenomere starting level to and just at base of solenophore, this base bearing 1-2 evident, mostly transversely directed outgrowths. India and Pakistan. ..

Kaschmiriosoma

2(1) Gonopod femorite usually devoid of a mesal groove; when present, it is short and simple. Base of solenomere clearly removed from that of solenophore. ................... 3

3(4) $O^{7}$ prefemur 1 with an adenostyle. Solenomere starting level to base of solenophore, each with a parabasal spine. Gonobelus

4(3) Adenostyles mostly absent, only rarely present on some $\sigma^{7}$ femora. Solenomere starting either clearly basal to or distally from solenophore, the former being devoid of evident spines. ............................................................ 5

5(6) Solenophore relatively poorly twisted, biramous, sometimes with a spine near bifurcation point; each solenophore arm in its turn clearly biramous. Solenomere start- 
ing from larger of solenophore arms, evidently distal to main bifurcation point. .................................. Wulingina

6(5) Solenophore very evidently coiled, uniramous. Solenomere starting clearly basal to solenophore (Figs 20 \& $30)$.

7(8) Gonopod femorite without mesal groove. Solenophore longer (Figs 16, 20 \& 21), with two evident spines (a and $\mathbf{b})$ at base, one of which may be retrorse (= directed basad).

Inversispina

8(7) Gonopod femorite with a simple, wide, mesal groove. Solenophore shorter (Figs 27, 30-32), with an evident lobe (l) at base. Belousoviella gen.n.

\section{Belousoviella gen.n.}

NAME. Honours Dr. Igor Belousov, a renowned Russian carabidologist who provided most of the material for the present study.

DESCRIPTION. Medium-sized (ca $2.5 \mathrm{~cm}$ long) Sulciferini with paraterga poorly developed, set mostly at $1 / 4$ to $1 / 3$ metasomital height. Adenostyles on $\sigma$ legs missing. A transverse setose lobe between $\sigma^{7}$ coxae 4 present.

Gonopod coxite elongate, much shorter than telopodite, subcylindrical, setose distoventrally. Prefemoral region as usual, densely setose, much shorter than femorite. The latter about as long as solenophore, elongate, somewhat enlarged distally, without processes, but with a broad, shallow, mesal groove, set off from solenophore by a distinct cingulum lying evidently distal to beginning of a flagelliform solenomere. Seminal groove on femorite entirely mesal; solenomere at base also entirely mesal, mostly sheathed by a rather short, distally complex, coiled solenophore supporting only a single lateral lobe (l) at base; both solenomere and solenophore directed laterad; the latter with a lamina lateralis and a lamina medialis subequally well developed, each ending by a lobe.

Type species: Belousoviella kabaki sp.n., by present designation.

DIAGNOSIS. Gonopod coxite only slightly shorter than femorite. The latter elongate, evidently enlarged distally, much longer than prefemoral portion and about as long as solenophore, without evidence of torsion. Solenophore complex, evidently coiled, with a lamina lateralis and a lamina medialis subequally well developed, concealing most of a long, flagelliform solenomere, with a considerable lateral lobe (I) near base; both solenophore and solenomere directed laterad. Solenomere starting well basal to solenophore.

\section{Belousoviella kabaki sp.n.}

Figs 22-32.

HOLOTYPE OT (ZMUM), China, Sichuan Prov., SW of Mianning, right tributary of Yalongjiang River Canyon, $28^{\circ} 13^{\prime} 11^{\prime \prime} \mathrm{N}$, $101^{\circ} 44^{\prime} 13^{\prime \prime E}$, ca $3360 \mathrm{~m}$ a.s.1., near upper timber-line, Rhododendron with broadleaved bushes and trees with abundant grassy patches, 06.VII.2011, leg. I. Belousov \& I. Kabak.

NAME. Honours Dr. Ilya Kabak, a renowned Russian carabidologist, one of the main collectors of the material treated here.
DESCRIPTION. Length ca $25 \mathrm{~mm}$, width of midbody pro- and metazona 1.8 and $2.3 \mathrm{~mm}$, respectively. General coloration in alcohol uniformly blackish brown; head, venter, as well as basal podo- (coxa, prefemur, sometimes also femur and postfemur) and antennomeres (except for $6^{\text {th }}$ and $7^{\text {th }}$ ) a little lighter, brown (Figs 22-27). Gonopod coxite and prefemoral part brown, acropodite yellowish (Fig. 27)

All other characters as in Inversispina erectispina sp.n., except as follows.

In width, head $>$ segment $2=5-16>$ collum $>$ segments 3 and 4; starting from segment 17, body gradually tapering towards telson.

Paraterga a little more strongly developed (Figs 22-27), with small, but evident shoulders anteriorly, as well as subspiniform caudal projections in segments 17 and 18; one incision/knob at lateral margin of callus in front of ozopore in poriferous segments, with two similar knobs in poreless ones. Body surface mostly smooth and shining, metaterga and sides often very faintly rugulose, sides below paraterga finely microgranulate. Axial line nearly missing, at most vague, barely visible only on some metaterga (Fig. 23). Transverse metatergal sulcus evident in segments 5-18, not reaching bases of paraterga. Tergal setae retained only on collum, arranged in three transverse rows, pattern on following metaterga traceable as $2+2$ insertion points in a front row. Stricture dividing pro- and metazona finely, but clearly ribbed at bottom down to about $1 / 2$ body height. Pleurosternal carinae virtually missing. Epiproct (Figs 24 \& 26) rather long, tip narrowly concave, subapical papillae very evident. Hypoproct (Fig. 28) semi-circular, caudal $1+1$ setae borne on minute knobs and evidently separated.

Sternites without modifications, sparsely setose, cross-impressions very modest; a round, linguiform, setose lamina with a pair of pores only between $\sigma^{7}$ coxae 4 (Figs 27 \& 29); the latter each with a small, but evident, distoventral, digitiform process (Fig. 27). Legs densely setose ventrally, obviously incrassate in $\sigma^{7}$ as compared to 9 (Figs 22-24), ca 1.2-1.3 times as long as midbody height; prefemora without evident lateral bulges; ventral brushes on tarsi present until two last leg-pairs; adenostyles wanting.

Gonopods (Figs 22, 27 \& 30-32) rather complex; coxite short, subcylindrical, setose distodorsally, only slightly shorter than femorite; the latter elongate, simple, evidently enlarged distally, much longer than prefemoral portion and about as long as solenophore, without evidence of torsion, but with a broad, shallow, mesal hollow; solenophore complex, evidently coiled, with a lamina lateralis and a lamina medialis subequally well developed, concealing most of a long, flagelliform solenomere, with a considerable lateral lobe (1) near base; both solenophore and solenomere directed laterad.

ACKNOWLEDGEMENTS. I am most grateful to Igor Belousov and Ilya Kabak (both St. Petersburg, Russia), as well as to Yuri Marusik (Magadan, Russia), who provided material for the present study. The pictures were skillfully 

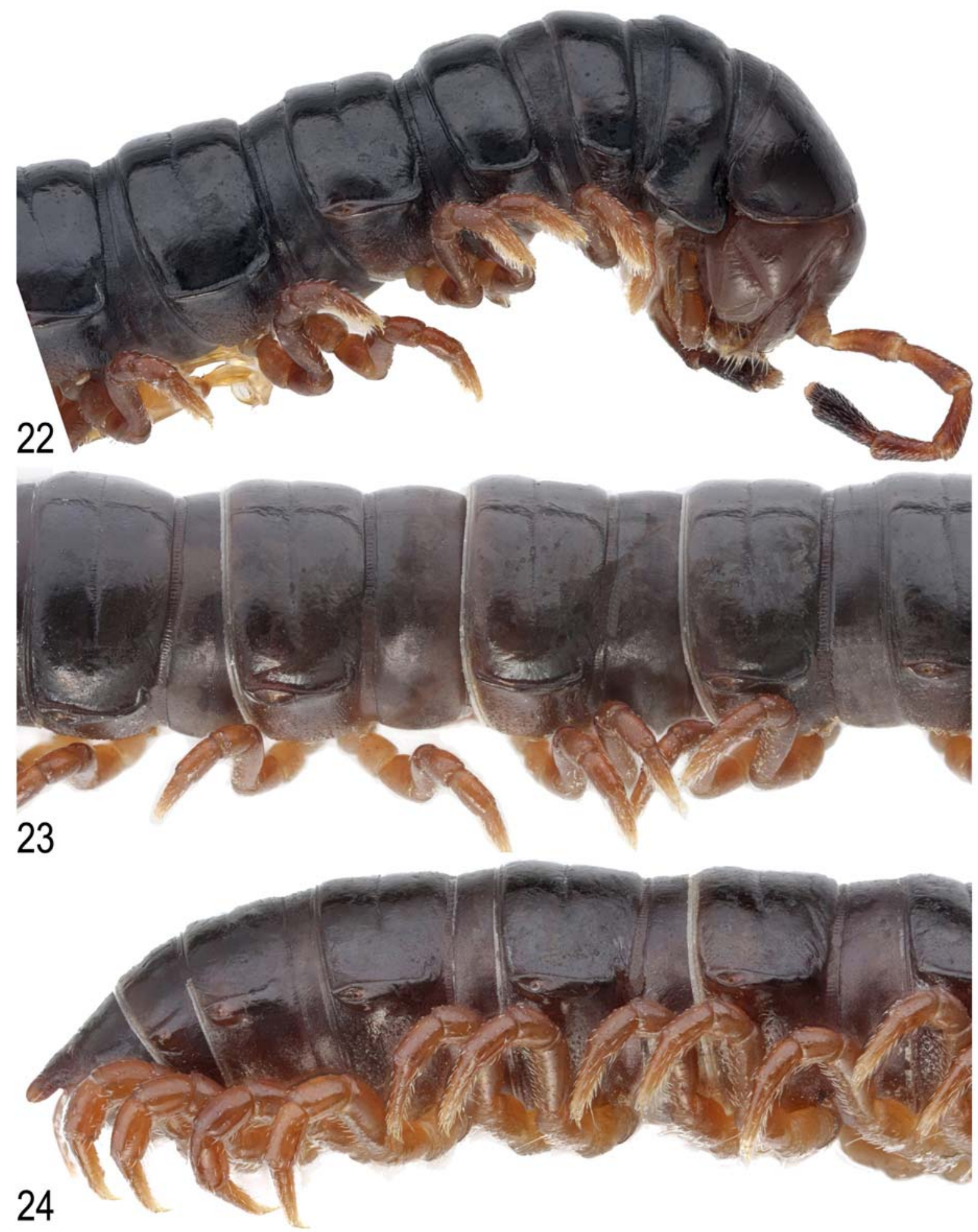

Figs 22-24. Belousoviella kabaki sp.n., $\bigcirc^{7}$ holotype: anterior, middle and caudal parts of body, respectively, lateral view. Photos taken by K. Makarov, not to scale.

Pис. 22-24. Belousoviella kabaki sp.n., голотип O: соответственно передняя, средняя и задняя части тела, вид сбоку. Фото сделаны К. Макаровым, без масштаба. 


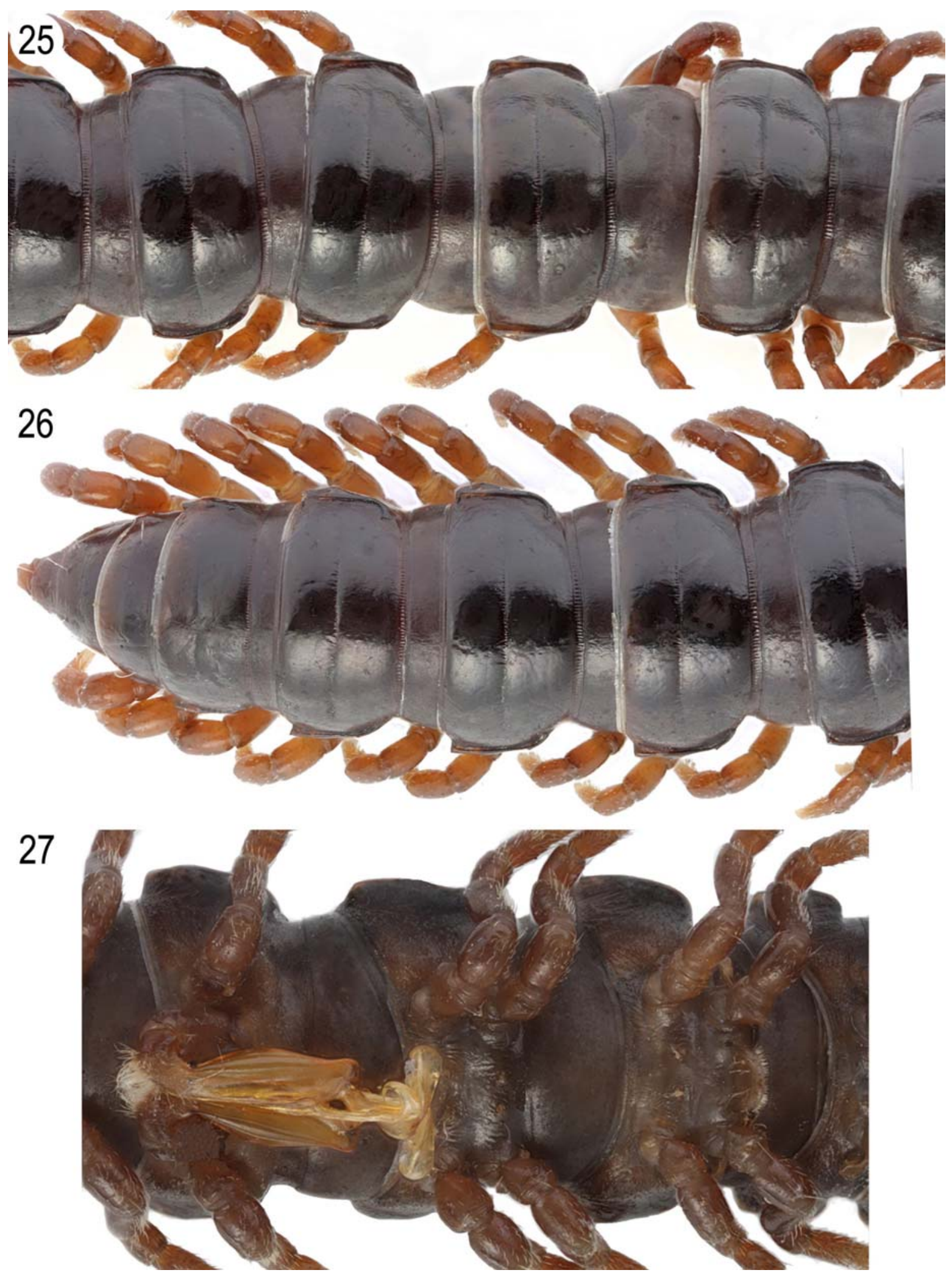

Figs 25-27. Belousoviella kabaki sp.n., $\sigma^{7}$ holotype: $25 \& 26$ - middle and caudal parts of body, respectively, dorsal view; 27 body segments 4-7, ventral view. Photos taken by K. Makarov, not to scale.

Pис. 25-27. Belousoviella kabaki sp.n., голотип О': 25 и 26 - соответственно средняя и задняя части тела, вид сверху; 27 туловищные сегменты 4-7, вид снизу. Фото сделаны К. Макаровым, без масштаба. 


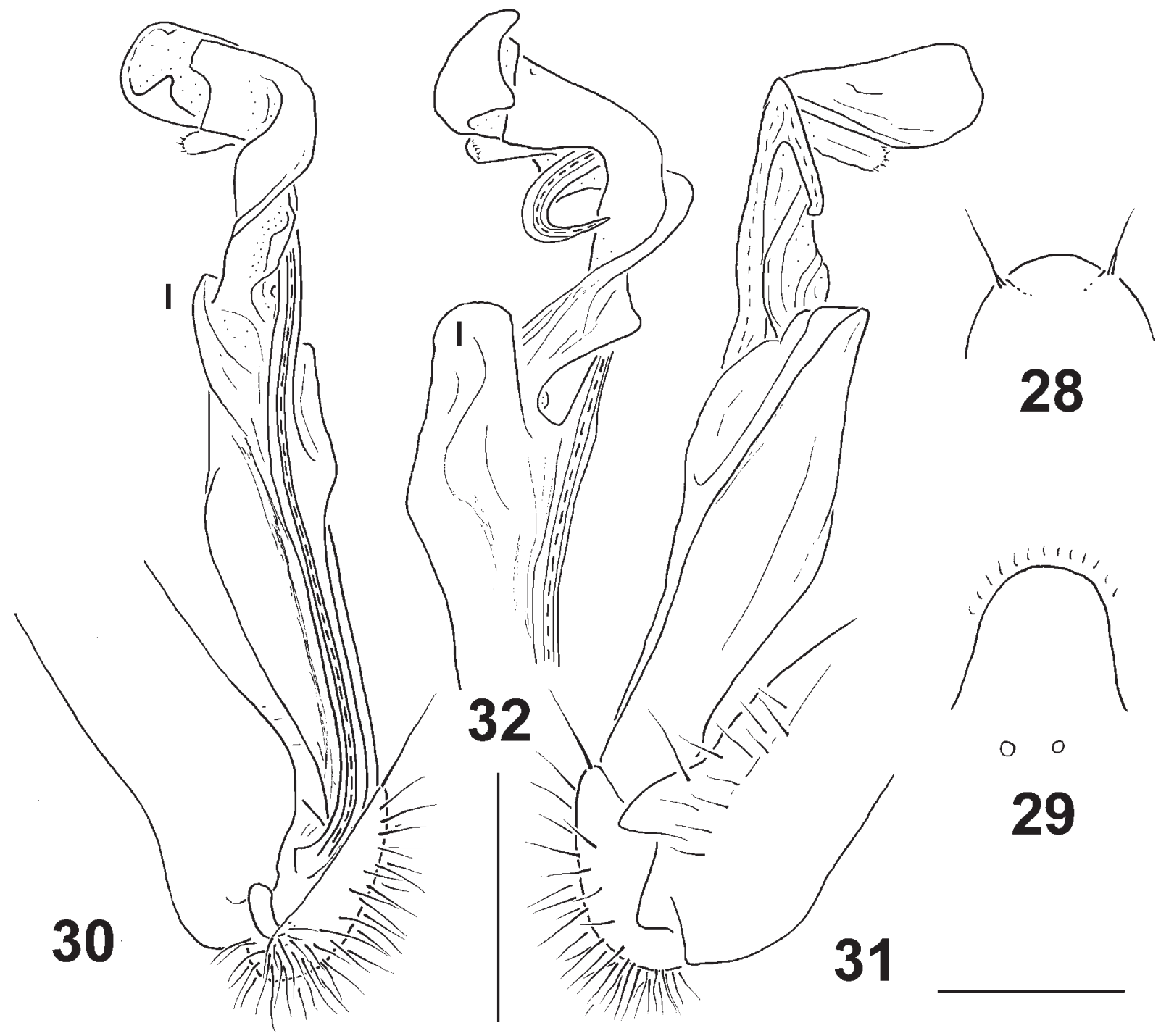

Figs 28-32. Belousoviella kabaki sp.n., $0^{7}$ holotype: 28 - hypoproct, ventral view; 29 - sternal lamina between coxae 4, caudal view; 30-32 - left gonopod, mesal, lateral and dorsal views, respectively. Scale bars: 0.5 (30-32) and 0.25 mm (28 \& 29).

Рис. 28-32. Belousoviella kabaki sp.n., голотип О7: 28 - гипопрокт, вид снизу; 29 - стернальная пластина между тазиками 4, вид сзади; 30-32 - левый гонопод, соответственно изнутри, сбоку и сверху. Масштаб: 0,5 (30-32) и 0,25 мм (28 и 29).

taken by K. Makarov (Moscow, Russia), kindly arranged into plates by N. Likhitrakarn (Bangkok, Thailand). This work has been supported in part through a grant released by the Russian Ministry of Education and Science.

\section{References}

Attems C. 1936. Diplopoda of India // Mem. Ind. Mus. Vol.11. No.4. P.133-323.

Attems C. 1937. Myriopoda 3. Polydesmoidea I. Fam. Strongylosomidae // Das Tierreich. Lfg.68. S.I-XXII, 1-300.

Chen C.C., Golovatch S.I., Chang H.W. 2011. The genus Inversispina Zhang, in Zhang, Wang et Zhang, 1997, new to the millipede fauna of Taiwan, with the description of a new species (Diplopoda, Polydesmida, Paradoxosomatidae, Alogolykinae) // Arthropoda Selecta. Vol.20. No.4. P.251-257.
Geoffroy J.-J., Golovatch S.I. 2004. Some polydesmidan millipedes from caves in southern China (Diplopoda: Polydesmida), with descriptions of four new species // Arthropoda Selecta. Vol.13. Nos 1-2. P.19-28.

Golovatch S.I. 2011. On several new or poorly-known Oriental Paradoxosomatidae (Diplopoda: Polydesmida), XI // Arthropoda Selecta. Vol.20. No. 4. P. 259-266.

Jeekel C.A.W. 1968. On the classification and geographical distribution of the family Paradoxosomatidae (Diplopoda, Polydesmida). Privately published. Academisch Proefschrift (PhD Thesis), Rotterdam. $162 \mathrm{pp}$.

Jeekel C.A.W. 1988. The generic position of Orthomorpha bucharensis Lohmander and O. muminabadensis Gulièka, and the taxonomic status of Hedinomorpha Verhoeff (Diplopoda, Polydesmida, Paradoxosomatidae) // Bull. Zoöl. Mus. Univ. Amsterdam. Vol.11. No.11. P.97-104.

Jeekel C.A.W. 2003. Paradoxosomatidae from North Pakistan, collected by Cl. Besuchet and I. Löbl in 1983 (Diplopoda, Poly- 
desmida) // Myriapod Memoranda. Vol.6. P.14-27.

Mikhaljova E.V. 2004. The millipedes (Diplopoda) of the Asian part of Russia. Sofia-Moscow: Pensoft. 294 pp

Verhoeff K.W. 1933. Schwedisch-chinesische wissenschaftliche Expedition nach den nordwestlichen Provinzen Chinas, unter Leitung von Dr. Sven Hedin und Prof. Sü Ping-Chang. Myriapoda gesammelt vom schwedischen Arzt der Expedition Dr. David Hummel 1927-1930 // Ark. Zool. Bd.26A. No.10. S.1-41.

Zhang C.Z., Tang H.Q. 1985. Eine neue Art der Gattung Hedi- nomorpha (Diplopoda, Paradoxosomatidae) aus China // Sinozoologia. No.3. P.35-38 [in Chinese, with German summary]. Zhang C.Z., Wang D.Q., Zhang F.X. 1997. [Two new genera and four new species of Diplopoda from Wuling Mountains area] // Song D.X. (ed.). Invertebrates of Wuling Mountains area, Southwestern China. Science Press, Beijing. P.508-522 [in Chinese, with English summary].

Responsible editor K.G. Mikhailov 